\title{
Evaluation of the performance of bio-oil obtained through pyrolysis of coffee waste
}

\author{
Monique Kort-Kamp Figueiredo ${ }^{1}$, Karolyne Nogueira de Castro Caldas², Beatriz Pereira do \\ Nascimento ${ }^{3}$, Priscila Schroeder ${ }^{4}$, Gilberto Alves Romeiro ${ }^{5}$ \\ ${ }^{1}$ Professor at Federal Institute of Education, Science and Technology of Rio de Janeiro - IFRJ, Duque de Caxias Campus, \\ Multidisciplinary Laboratory of Waste Management - LMGR \\ 2,3Student at Federal Institute of Education, Science and Technology of Rio de Janeiro - IFRJ, Duque de Caxias Campus, \\ ${ }^{4}$ Doctoral Student of Fluminense Federal University - UFF, Chemistry Laboratory - LABCON. \\ ${ }^{5}$ Professor at Fluminense Federal University - UFF, Chemistry Laboratory - LABCON. \\ monique.figueiredo@ifrj.edu.br.
}

\begin{abstract}
Bio-oils are a complex blend of organic compounds formed by fragmentation of the structures present in biomass after undergoing a thermal process known as pyrolysis. Coffee waste is an organic residue discarded in large quantities in Brazil. This work aimed to evaluate some chemical and physicochemical characteristics of this oil, to seek economically viable uses for the product. Five pyrolysis procedures were employed and an average bio-oil yield of $18 \%$ was obtained. The oil was subjected to tests such as infrared, pour point and ash content. Infrared spectroscopy revealed an intense aliphatic character of the structure, which also had considerable presence of oxygen due to the presence of functional groups such as carbonylates, carboxylates, esters, ketones, amides and ether, as well as aromatics. The pour point determined for the bio-oil was $20^{\circ} \mathrm{C}$ and the ash content was less than $1 \%$.
\end{abstract}

Keywords: Bio-oil, pyrolysis, coffee waste.

\section{Introduction}

Coffee grounds are a common household waste, especially in large urban centers, since coffee is the second most consumed beverage in Brazil (Embrapa, 2017). According to the International Euromonitor Report developed by the Brazilian Coffee Industry Association in April 2016, the slowdown in growth, the recent economic crisis has not strongly affected coffee consumption, since it is habit-forming and inexpensive. In addition, new brewing technologies such as capsules promote coffee consumption (Embrapa, 2017).

According to data from the Annual Evaluation of Coffee Industry Indicators in Brazil: Production and Internal Consumption Performance/2015, prepared by the Brazilian Coffee Industry Association's research area, in 2010 per capita consumption of roasted coffee in Brazil reached $4.81 \mathrm{~kg}$ per person, almost 81 liters of coffee per person, setting a new record. Table 1 shows the evolution of coffee consumption from 2010 to 2015 in Brazil (ABIC, 2017). 
Table 1 - Consumption of coffee in Brazil, in kg/person year, between 2010 and 2015.

\begin{tabular}{ccc}
\hline \multirow{2}{*}{ Year } & \multicolumn{3}{c}{$\begin{array}{c}\text { Consumption per person } \\
(\mathrm{Kg} / \text { person/year })\end{array}$} \\
\cline { 3 - 4 } & Green coffee & Roasted coffee \\
\hline 2010 & 6.02 & 4.81 \\
2011 & 6.10 & 4.88 \\
2012 & 6.23 & 4.98 \\
2013 & 6.09 & 4.87 \\
2014 & 6.12 & 4.89 \\
2015 & 6.12 & $\mathbf{4 . 9 0}$ \\
\hline
\end{tabular}

In 2013, coffee consumption decreased by $1.23 \%$ compared to the previous year. However, due to the development of new segments and the stability of the coffee market, this retraction was recovered the following year, when there was a $1.24 \%$ increase in the total consumption. In 2015, there was a new increase of $0.86 \%$, with total consumption of 20,508 million bags and per capita consumption of 4.90 $\mathrm{kg} /$ person (ABIC, 2017).

According to the Coffee Statistical Report, from the Coffee Department, since the creation of the Consórcio Pesquisa Café (Coffee Research Consortium), the evolution of coffee production has been significant way. So, it is possible to conclude that researchers and industry are working together to increase the consumption of coffee worldwide. Due to the investments and the solidity of the coffee market, demand is generally expanding, as are the volumes of discarded waste (Embrapa, 2017).

This residue in general is coffee sludge, which is a biomass that can be converted into solid, liquid or gaseous fuels through thermochemical, biochemical or mechanical processes (Bridgewater, 2012).

Residual biomass is the residue of materials of organic origin. Chemically, it is a heterogeneous material with high moisture content, low calorific value and fixed carbon. The mentioned conversion processes are responsible for the modification (rupture and rearrangement) of the molecules of the compound (Oliveira et al., 2011). Brazil has developed technologies for the use of biomass seeking energy sustainability through those processes.

The chemical composition of coffee beans depends on many factors, such as the harvesting methods. Its main constituents are high and low molecular weight carbohydrates and some organic acids. The main acids found in coffee are chlorogenic, quinic, malic, citric and phosphoric acids. The main nitrogen compounds present in brewed coffee are caffeine, trigonelline, amino acids and proteins. Although coffee beans are not classified as oilseeds, coffee grounds contain about 10 to $15 \%$ saturated and unsaturated fatty acids, which can be extracted and harnessed.

Pyrolysis is the thermal decomposition of a biomass in total or partial absence of oxygen or in an environment capable of avoiding the gasification of the material, in order to generate products that have a higher energy density than the biomass (Kimura, 2009). When the residual biomass is converted by a pyrolytic process, three fractions are generated: gas, solid and liquid. The quantity and quality of each product depends on process parameters such as temperature, heating rate and residence time of the vapors, among others. In this study, the soft pyrolysis process was used, where the biomass is submitted to low temperatures and long residence time, aiming to produce the three fractions.

Biochar is composed mainly of carbonized coffee grounds and ash, also containing volatile matter and water. It is widely used in agriculture to improve the chemical, physical and biological properties of soil. It can also be used as an adsorbent material or solid fuel (Schroeder, 2017).

The gas fraction is composed of $\mathrm{CO}_{2}$ (carbon dioxide) and $\mathrm{CO}$ (carbon monoxide), which are generated by reoxidation of the carbons that form the raw material. This gas does not really contribute to the greenhouse effect since only restores to the atmosphere the carbon absorbed by the biomass (Santos, 2011). In addition, $\mathrm{H}_{2} \mathrm{O}$ (water), $\mathrm{H}_{2}$ (hydrogen gas) and even light hydrocarbons such as $\mathrm{CH}_{4}$ (methane), $\mathrm{C}_{2} \mathrm{H}_{4}$ (ethene), $\mathrm{C}_{2} \mathrm{H}_{6}$ (ethane), can be formed (Schroeder, 2017). 
The liquid fraction obtained in the pyrolysis process is a complex mixture of several components from the depolymerization and fragmentation of macromolecules (cellulose, hemicellulose and lignin) (Schroeder, 2017). This blend can be composed of acids, alcohols, aldehydes, ketones, phenols, ethers, esters, sugars, furans, alkenes, nitrogen compounds and other oxygenates (Calixto, 2017). It can be emulsified in water or separated into two phases: one aqueous and the other organic.

In turn, bio-oil-is also referred as pyrolysis oil, wood liquids, condensed smoke, wood distillate or pyrolignal tar, among others (Rocha, 2004) - is one of the most desired products of the three obtained by pyrolysis because of its high calorific power and its possible uses in fine chemistry, such as to produce hydrocarbons, fatty acids, aromatics and carboxylic acids (Romeiro et al., 2012). In the present work, the chemical composition and physical-chemical characteristics of the bio-oil obtained from the soft pyrolysis of coffee waste were studied, to enable transforming this residue into an economically viable material.

\section{Materials and methods}

\subsection{Materials}

The raw material used in the procedure was collected in the residences of the authors. Initially, the sample underwent a drying process in an electric oven until reaching constant weight. The system consisted of a Heraus R/O 100 oven with temperature and operating time controller, fixed bed made of boron-silicate glass with ground-type joints (Pirex - dimensions $1.40 \mathrm{~cm} \mathrm{X} 10 \mathrm{~mm}$ ), a liquid collection system consisting of a condenser, settling funnel $(500 \mathrm{~mL})$ and three gas scrubber flasks. The process was conducted in a batch reactor.

For the pyrolysis process, 500 grams of biomass (processed coffee grounds) was placed in the fixed bed of glass. This was inserted into the reactor and the process of inerting the environment was initiated with passage of nitrogen gas for 10 minutes before starting the conversion. The reaction process was then started by raising the temperature to $400{ }^{\circ} \mathrm{C}$ (average temperature for mild pyrolysis) at a heating rate of 15 ${ }^{\circ} \mathrm{C} / \mathrm{min}$. After 120 minutes, the reactor was shut down. The liquid fraction was recovered in a funnel after separation through a condensation system. Biochar was trapped inside the reactor and was recovered after cooling of the system. The gases released passed through a gas scrubber system where they were bubbled in water. Figure 1 shows a simplified diagram of the reactor used in the conversion process.

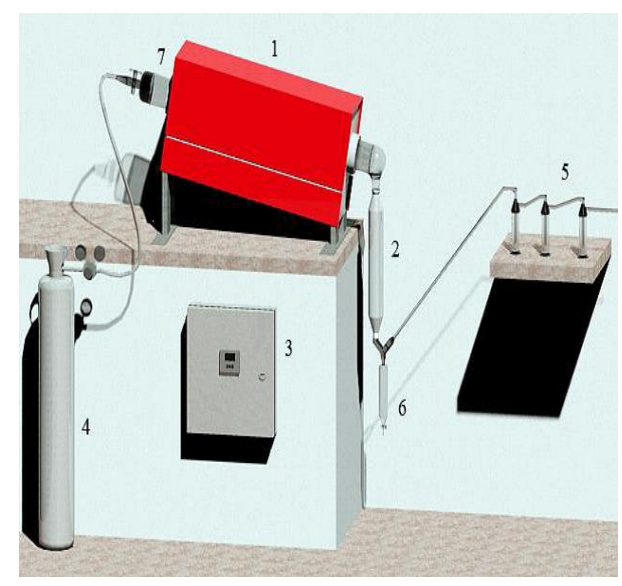

Figure 1 - Thermoelectric reactor for low-temperature conversion in batch mode. (1) pyrolytic reactor; (2) condenser; (3) temperature controller; (4) nitrogen cylinder; (5) flushing flasks; (6) liquid fraction collector; (7) borosilicate bed.

After the pyrolysis procedure, the bio-oil was separated from the aqueous waste in a separation funnel by density difference. Analyses were then carried out in order to determine the chemical and physicochemical characteristics. 


\subsection{Analysis}

Infrared analyses of coffee grounds and bio-oil were carried out to observe the structural modifications that occurred due to the thermal decomposition of the material. The samples were submitted to Fourier-transform infrared spectroscopy with a Varian 7000e FT-IR spectrometer.

The pour point of the bio-oil was also analyzed in a manual device, according to the Brazilian standard NBR 11349, at temperatures around $3{ }^{\circ} \mathrm{C}$.

The ash content was determined in a muffle furnace at a temperature of about $750{ }^{\circ} \mathrm{C}$, where the material was maintained until complete calcination, according to ASTM D1762-84.

\subsection{Statistical analysis}

The statistical significance of the pyrolysis procedures among the triplicates was ascertained by the Scott-Knott test (Scott \& Knott, 1974). The same was used to test for significant differences between the triplicate results. All calculations in this work were performed by Assitat 7.7 (Silva \& Azevedo, 2016).

\section{Results and discussion}

According to Technical Standard NBR 10.004: Solid Waste Classification (ABNT, 2004), this coffee waste is classified as Class II A, Not Hazardous - Not Inert.

The average values of the five pyrolysis procedures are shown in Table 2. For the procedure with bio-oil the best yield was found in the first pyrolysis $(21.0 \%)$. The fifth procedure presented the worst yield $(16.0 \%)$. Additionally, for aqueous fraction, the best yield was produced by the second procedure (43.0\%) and the worst yield (23.0\%) was obtained with the fourth procedure. For the biochar fraction, the best yield was obtained from the fourth procedure (37.5\%) and the worst $(33.0 \%)$ from the first procedure. Finally, the highest gas fraction was obtained with the fourth procedure $(23.5 \%)$ and the worst $(5.5 \%)$ from the second procedure. These variations may have occurred due to how the residue was placed in the converter tube, variation in the quantity inserted, and moisture content of the raw material. In particular, we detected a small leak in the system at the time of conversion, causing a greater yield of the gas phase in the fourth and fifth procedures. Another cause of the difference in yields is the separation of the liquid phase into bio-oil and aqueous material, because the different times employed to separate the phases may have led to greater or lesser emulsification or solubilization of the phases.

Table 2 - Yields of the products obtained in the pyrolysis process.

\begin{tabular}{ccccc}
\hline Yields (\%) & Bio-oil & Aqueous fraction & Biochar & Gas Fraction \\
\hline 1 & $21.0 \mathrm{a}$ & $28.5 \mathrm{a}$ & $33.0 \mathrm{a}$ & $18.0 \mathrm{a}$ \\
2 & $19.5 \mathrm{~b}$ & $43.0 \mathrm{~b}$ & $32.0 \mathrm{a}$ & $5.5 \mathrm{~b}$ \\
3 & $18.5 \mathrm{~b}$ & $29.5 \mathrm{a}$ & $33.5 \mathrm{a}$ & $18.5 \mathrm{a}$ \\
4 & $16.0 \mathrm{c}$ & $23.0 \mathrm{~d}$ & $37.5 \mathrm{~b}$ & $23.5 \mathrm{c}$ \\
5 & $16.0 \mathrm{c}$ & $27.3 \mathrm{c}$ & $34.0 \mathrm{a}$ & $22.7 \mathrm{c}$
\end{tabular}

Table 2. Evaluation of the percentage yields of the pyrolysis procedures. The average values followed by the same lowercase letter in column do not differ statistically from each other by the Scott-Knott test $(\mathrm{p}<0.01)$.

The physical characteristics of the bio-oil revealed it is an extremely complex substance, formed by the mixture of several compounds generated by the thermal decomposition of lignin, cellulose and hemicellulose, the predominant structures of the initial biomass. In order to make the bio-oil commercially viable, it is necessary to know the structures present in this substance and its components. The infrared technique provides information about the organic functions contained in the sample, thus helping to 
elucidate the molecular structure. Below, the infrared spectra obtained for the coffee waste (Figure 1) and bio-oil (Figure 2) are shown.

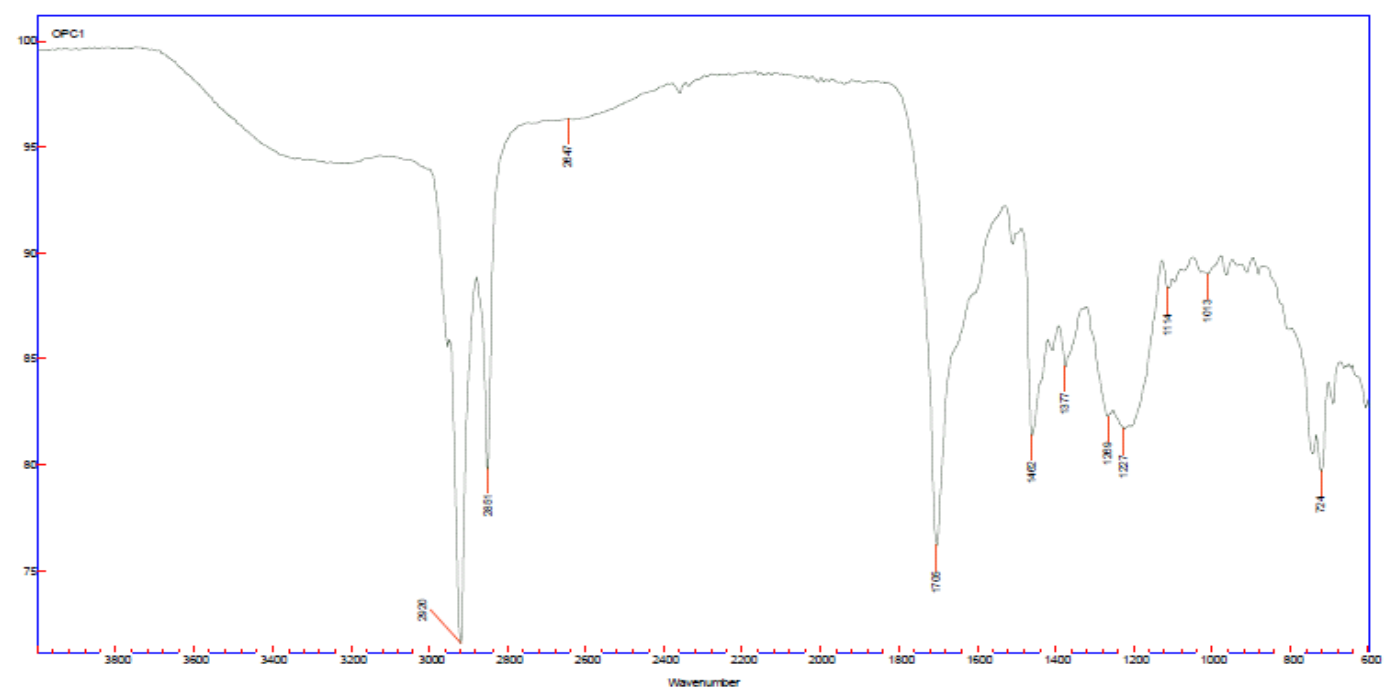

Figure 2. Infrared spectrum of coffee grounds.

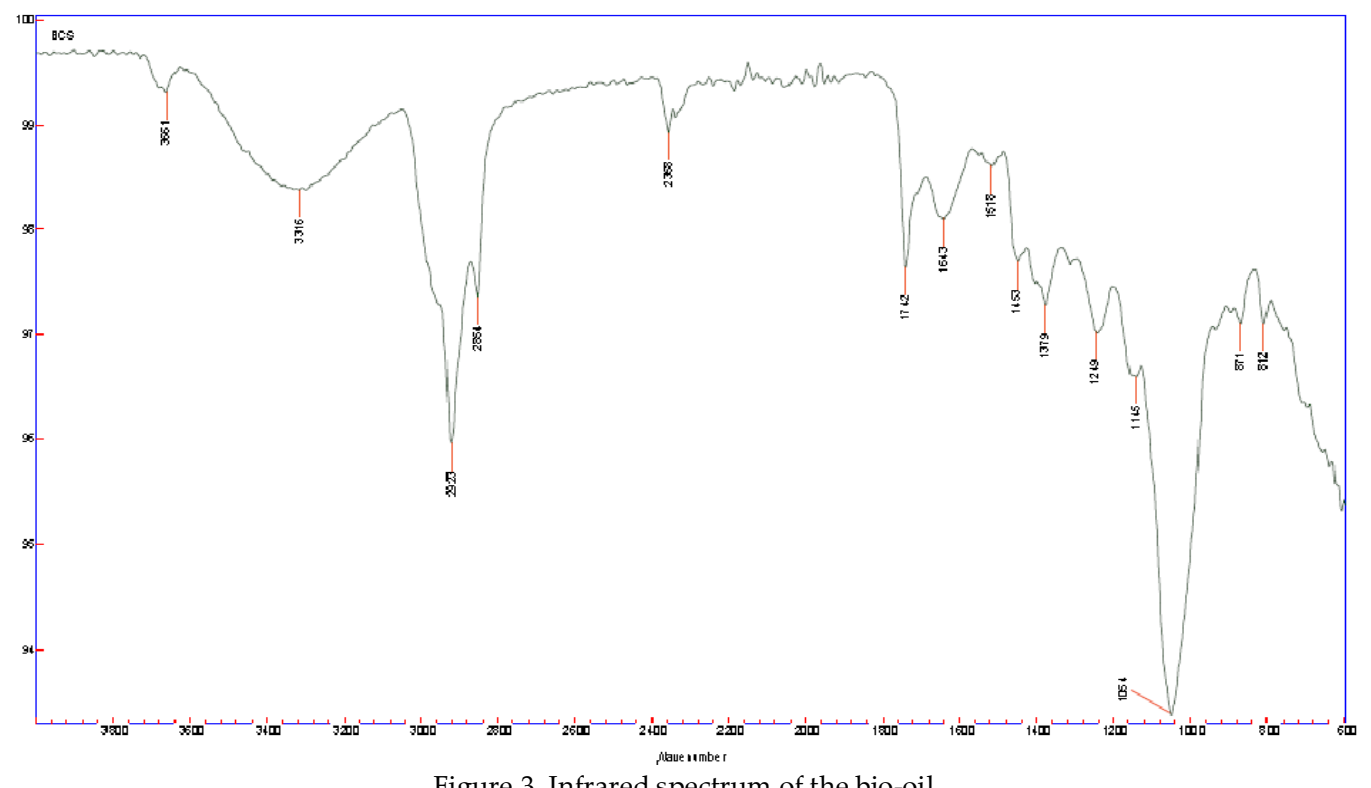

In the infrared spectrum of the coffee grounds (Figure 2), we found high incidence of sulfoxide due to the absorption in the $1054 \mathrm{~cm}^{-1}$ region, attributed to this compound. The spectrum also indicates the presence of other sulfur and nitrogen compounds, as well as carbonyl functional groups such as esters and the presence of less aromatic compounds.

In the infrared spectrum of the bio-oil (Figure 3), it is possible to observe the intense aliphatic character after conversion, since the greatest absorption occurred in the regions of 2920 and $2851 \mathrm{~cm}^{-1}$, attributed to the compounds $\mathrm{CH}_{3}$ and $\mathrm{CH}_{2}$. The structure also has a considerable occurrence of oxygen due 
to the presence of the same carbonylated and carboxylated functional groups present in the sludge, as well as new compounds such as ketones, amides and ether, with an increase in aromatics.

Comparing the spectra before (sludge spectrum) and after pyrolysis (bio-oil spectrum), one can perceive the increase in absorption in the regions between $2700 \mathrm{~cm}^{-1}$ and $3600 \mathrm{~cm}^{-1}$, which are attributed to the occurrence of aliphatic $\mathrm{CH}$ molecules. Thus, the pyrolyzed mass had higher content of the most useful organic compounds, as had been predicted. In addition to the decrease in the presence of sulfur and nitrogen compounds, there was an increase in aromatic compounds and the occurrence of oxygen due to the increased incidence of oxygenated functional groups.

Pour point

The pour point determined for the bio-oil was $20^{\circ} \mathrm{C}$. This was expected due to the characteristics previously observed in the oil. The National Petroleum Agency (ANP, acronym in Portuguese), the agency responsible for regulating petroleum, natural gas and biofuels, determines that the minimum cold filter clogging point for a biofuel is $9{ }^{\circ} \mathrm{C}$, far below the oil's pour point. This parameter means the bio-oil cannot be used as an automotive fuel.

Ash content

The ash content test was also performed, but due to the low amount of ash remaining after reaching constant weight, a content of less than $1 \%$ was considered. According to the ANP, the maximum ash content for automotive diesel oil is $0.01 \%$ by mass.

Ashes are inorganic wastes that remain after burning organic matter. Thus, the higher the ash content, the more inorganic waste will be discharged into the environment. (Conceição et al., 1998)

\section{Conclusion}

There are much more stringent prevention and control measures required for the disposal of petroleum and agrochemical resides than for coffee waste. Therefore, these results highlight the importance of greater control and prevention of inappropriate coffee waste disposal.

\section{Acknowledgments}

Pibiti Jr. gratefully acknowledges the grant from IFRJ. CNPq and FAPERJ provided financial support.

\section{References}

ABIC, Associação Brasileira da Indústria de Café. (2017) Estatística do Consumo Interno. Available at: URL <http://www.abic.com.br> Consulted: 30 July 2017

ASSOCIAÇÃO BRASILEIRA DE NORMAS TÉCNICAS. NBR 10.004: Resíduos sólidos Classificação. Rio de Janeiro: 2004.

BRIDGWATER, A.V.; (2012) Upgrading biomass fast pyrolysis liquids. American Institute of Chemical Engineers, April 2012.

CALIXTO, G.Q.; (2016) Caracterização energética e avaliação dos produtos da pirólise rápida de resíduos agrícolas regionais. Universidade Federal do Rio Grande de Norte, RN, December 2016. 
CONCEIÇÃO, M.M.; MACEDO, R.O.; SOUZA, A.G. (1998) Determinação do teor de umidade e cinzas e análise cinética do milho e derivados. Anais da Associação Brasileira de Química, v. 47, n.4, pp. 361-367.

EMBRAPA, Consórcio Pesquisa Café. (2017) Informe Estatístico do Café. Available at: $<$ http://www.consorciopesquisacafe.com.br $>$ e $<$ www.embrapa.br/cafe $>$ Consulted: 30 July 2017.

NASSIF, L. (2017) Brasil tem vantagens em biomassa residual. O Jornal de todos os Brasis, 2010. Available at: $<$ http://jornalggn.com.br $>$. Consulted: 23 July 2017

OLIVEIRA A.L.; (2011) Desenvolvimento de uma unidade pirolítica com reator de cilindro rotativo: Obtenção de bio-óleo. Universidade Federal do Rio Grande do Norte, RN, May 2011.

ROCHA, J.D. et al; (2004) Aspectos Teóricos e Práticos do processo de pirólise de biomassa. Universidade Estadual de Campinas, Faculdade de Engenharia Agrícola, Bioware Tecnologia, SP, July 2004.

ROMEIRO, G.A. et al; (2012) A study of pyrolysis oil from soluble coffee ground using low temperature conversion (LTC) process. Journal of Analytical and Applied Pyrolysis, v. 93, pp. 4751, 2012.

SANTOS, G. K.; (2011) Aspectos fundamentais da pirólise de biomassa em leito de jorro: Fluidodinâmica e cinética do processo. (tese doutorado), Universidade Federal de Uberlândia, MG, November 2011.

SCHROEDER, P.; (2017) Obtenção, avaliação e aplicações de bioprodutos obtidos da semente da graviola (Annona Muricata): processos químicos e termoquímicos. (dissertação de mestrado), Universidade Federal Fluminense, RJ, February 2017.

SCOTT, A. J.; KNOTT, M. A. (1974) A Cluster analysis method for grouping means in the analysis of variance. Biometrics. Raleigh, v.30, n.3, pp. 507-512. September.

SILVA, F. de A. S. and; AZEVEDO, C. A. V. DE. (2016) The Assistant Software Version 7.7. and its use in the analysis of experimental data. Afr. J. Adric. Res, v.11, n.39, pp. 3733-3740. 